\title{
HUBUNGAN KEAKTIFAN PRAKTIKUM DENGAN HASIL EVALUASI UJIAN ANTENATAL CARE PADA MAHASISWA PRODI DIII KEBIDANAN STIKES MAMBA'UL 'ULUM SURAKARTA
}

\section{Relationship of Practicum Activity with Evaluation Result of Antenatal Care Examination at Student of Diploma Program of Midwifery in STIKES Mamba'ul 'Ulum Surakarta.}

\author{
Anita Dewi Lieskusmastuti1, Danik Riawati2 \\ STIKES Mamba'ul 'Ulum Surakarta \\ (anita.dewi712@yahoo.co.id)
}

\begin{abstract}
ABSTRAK
Latar Belakang: Antenatal Care merupakan pelayanan yang diberikan tenaga profesional yang diberikan pada ibu hamil sesuai dengan standar pelayanan antenatal. Mahasiswa Diploma III Kebidanan juga diharapkan mempunyai kemampuan dalam memberikan pelayanan kehamilan yang berkualitas. Proses belajar akan berlangsung dengan baik, apabila mahasiswa aktif. Bahwa segala pengetahuan dan keterampilan harus diperoleh sendiri melalui pengamatan, pengalaman, penyelidikan, dengan bekerja sendiri dan fasilitas yang diciptakan sendiri dalam hal kegiatan belajar meliputi keaktifan praktikum peserta didik di laboratorium. Penelitian ini bertujuan untuk mengetahui hubungan antara keaktifan praktikum dengan hasil evaluasi ujian antenatal care pada mahasiswa Prodi DIII Kebidanan STIKES Mamba'ul 'Ulum Surakarta.
\end{abstract}

Metode: Penelitian ini menggunakan metode deskriptif korelatif dengan pendekatan potong lintang. Populasi penelitian ini adalah semua mahasiswa semester V Prodi DIII Kebidanan STIKES Mamba'ul 'Ulum Surakarta Tahun Akademik 2017-2018 sebanyak 34 responden. Teknik pengambilan sampel yang digunakan adalah Sampling Jenuh. Alat pengumpulan data berupa cheklist. Analisa data menggunakan uji Pearson Product Moment.

Hasil: Keaktifan praktikum Mahasiswa mayoritas termasuk kategori tinggi sebanyak 32 responden (88,2\%). Hasil evaluasi ujian ANC Mahasiswa mayoritas termasuk kategori baik sebanyak 16 responden $(47,1 \%)$. Ada hubungan signifikan antara keaktifan praktikum dengan hasil evaluasi ujian ANC Pada Mahasiswa Prodi DIII Kebidanan STIKES Mamba'ul 'Ulum Surakarta yaitu dengan nilai $p(0,000)<0,005$.

Simpulan: Ada hubungan signifikan antara keaktifan praktikum dengan hasil evaluasi ujian ANC Pada Mahasiswa Prodi DIII Kebidanan STIKES Mamba'ul 'Ulum Surakarta.

Kata Kunci: Keaktifan Praktikum, Hasil Evaluasi, Ujian Antenatal Care, Mahasiswa DIII Kebidanan 


\begin{abstract}
Background: Antenatal Care is a service provided by professionals given to pregnant women in accordance with antenatal care standards. Diploma III Midwifery students are also expected to have the ability to provide quality pregnancy services. The learning process will take place well, if students are active. That all knowledge and skills must be obtained by self-observation, experience, investigation, self- employed and self-created facilities in terms of learning activities include the activity of lab students in the laboratory. This study aims to determine the relationship between the activeness of the practice and the evaluation of antenatal care examination on the students of Diploma Program of Midwifery Three High School of Mamba'ul 'Ulum Surakarta Health Sciences.
\end{abstract}

Method: This research used descriptive correlative method with cross sectional approach. The population of this study is all students of the semester V Diploma Program Three Midwifery School of Health Sciences Mamba'ul 'Ulum Surakarta Academic Year 2017-2018 as many as 34 respondents. The sampling technique used is Saturated Sampling. The data collection tool is cheklist. Data analysis in this research using Pearson Product Moment test.

Result: Activity Activity of Diploma Program of Midwifery Students of Mamba'ul 'Ulum Surakarta High School of Health Sciences mostly belong to high category as many as 32 respondents (88,2\%). ANC exam evaluation result Student of Diploma Program of Three Midwifery High School of Health Sciences Mamba'ul 'Ulum Surakarta majority is good category as many as 16 respondents $(47,1 \%)$. There is a significant correlation between the activity activity and the evaluation result of ANC examination of Midwifery Diploma Program of High School of Mamba'ul 'Ulum Surakarta Health Sciences with $p$ value $(0.000)<0,005$.

Conclusion: There is a significant relationship between the activity of the lab and the ANC exam evaluation result on the Student Diploma Program of Midwifery School of Mamba'ul 'Ulum Surakarta.

Keywords: Practicum Activity, Evaluation Result, Antenatal Care Exam, Diploma Three Midwifery Student

\title{
PENDAHULUAN
}

Pelayanan antenatal berkualitas dalam program KIA merupakan kegiatan untuk menurunkan angka kesakitan dan kematian ibu dan anak yang terdiri dari pemeriksaan kesehatan, pengamatan, dan pendidikan kepada ibu hamil secara terstruktur dan terencana untuk mendapatkan suatu proses kehamilan dan persalinan yang aman. (Marniyati, 2016)

Indonesia tidak semua perempuan hamil akan melakukan pemeriksaan di awal kehamilannya. Sering ditemukan ibu hamil datang ke tenaga kesehatan saat usia kehamilan memasuki trimester II. Pada keadaan tersebut, ibu haruslah diberikan tambahan asuhan seperti pada trimester I 
sehingga penapisan terhadap penyulit kehamilan akan tetap dapat terdeteksi dengan baik. Bidan dapat melakukan penegakkan diagnosis kehamilan dengan melakukan pemeriksaan kehamilan, keadaan janin dan masalah yang mungkin menyertai kehamilannya. (Irianti, B, dkk, 2013)

Antenatal Care merupakan pelayanan yang diberikan tenaga profesional yang diberikan pada ibu hamil sesuai dengan standar pelayanan antenatal. Pemeriksaan ini bertujuan memeriksa keadaan ibu dan janin secara berkala. (Yanuaria, 2013) Mahasiswa Diploma III Kebidanan juga diharapkan mempunyai kemampuan dalam memberikan pelayanan kehamilan yang berkualitas. Evaluasi mahasiswa program studi Diploma III kebidanan dalam melaksanakan pemeriksaan kehamilan diwujudkan pada Ujian Antenatal Care dengan penerapan metode pembelajaran dalam bentuk teori dan praktik yang berbasis kompetensi. (STIKESMUS, 2017)

Hasil penelitian sebelumnya tentang hubungan metode pembelajaran simulasi dan belajar mandiri dengan hasil evaluasi belajar ANC menunjukkan bahwa terdapat hubungan yang signifikan metode pembelajaran simulasi dan belajar mandiri dengan hasil evaluasi belajar Asuhan Antenatal Care (ANC) di Akademi Kebidanan Ika Bina Labuhanbatu, melalui uji simultan (ANOVA) yaitu $F=14,750$, dan $p=0,000$. (Tanjung, 2016)

Proses belajar akan berlangsung dengan baik, apabila mahasiswa aktif. Bahwa segala pengetahuan dan keterampilan harus diperoleh sendiri melalui pengamatan, pengalaman, penyelidikan, dengan bekerja sendiri dan fasilitas yang diciptakan sendiri dalam hal kegiatan belajar meliputi keaktifan praktikum peserta didik di laboratorium. Keaktifan praktikum meliputi persiapan fisik dan mental dalam persiapan ujian Antenatal Care bagi mahasiswa program studi Diploma III kebidanan sangat diperlukan untuk menentukan kemampuan mengaplikasikan tindakan asuhan kebidanan pada ibu hamil sesuai dengan standar praktik bidan. (Sardiman, 2012)

Pelayanan pemeriksaan kehamilan standar $10 \mathrm{~T}$ meliputi pengukuran tinggi badan cukup satu kali dan penimbangan berat badan setiap kali periksa, pegukuran tekanan darah, pengukuran lingkar lengan atas, pengukuran tinggi rahim, penentuan letak janin dan penghitungan denyut jantung janin, penentuan status imunisasi Tetanus Toksoid (TT), pemberian tablet tambah darah, tes laboratorium, konseling serta tata laksana atau mendapatkan pengobatan. (Kemenkes RI, 2015). STIKES Mamba'ul 'Ulum Surakarta menerapkan evaluasi ujian ANC berdasarkan pedoman kurikulum Diploma Kebidanan. Dan didapatkan hasil evaluasi ujian ANC pada tahun 2016 yaitu prestasi belajar mahasiswa tidak hanya ditentukan dengan membaca dan mendengarkan saja, melainkan dengan adanya aktivitas mahasiswa di kelas teori dan praktik antenatal care di laboratorium sehingga dapat mempersiapkan mahasiswa dalam menerapkan asuhan kebidanan pada ibu hamil sesuai standar praktik kebidanan serta dapat meningkatkan kemampuan mahasiswa mencakup komponen pengetahuan, sikap dan keterampilan memberikan pelayanan antenatal berkualitas. Berdasarkan uraian diatas perlu diadakan penelitian lebih lanjut tentang Hubungan 
Keaktifan Praktikum Dengan Hasil Evaluasi Ujian Antenatal Care Pada Mahasiswa Prodi DIII Kebidanan STIKES Mamba'ul 'Ulum Surakarta.

\section{METODE PENELITIAN}

Penelitian ini merupakan penelitian deskriptif korelatif dengan pendekatan potong lintang. Populasi penelitian ini adalah semua mahasiswa semester V Prodi DIII Kebidanan STIKES Mamba'ul 'Ulum Surakarta Tahun Akademik 2017-2018 sebanyak 34 responden. Teknik pengambilan sampel yang digunakan adalah Sampling Jenuh.

Alat pengumpulan data yang digunakan dalam penelitian ini adalah cheklist. Checklist digunakan untuk mengukur keaktifan praktikum dan Hasil Evaluasi Ujian ANC. Metode pengumpulan data yang digunakan adalah pengumpulan data primer dan sekunder. Data- data yang sudah terkumpul kemudian dilakukan pengolahan data meliputi Editing, Coding, Tabulating dan Entering. Analisa data dalam penelitian ini menggunakan uji Pearson Product Moment.

\section{HASIL DAN PEMBAHASAN}

Tabel 1 Deskrispsi Data Penelitian

\begin{tabular}{lccccc}
\hline \multicolumn{1}{c}{ Variabel } & N & Minimum & Maximum & Mean & $\begin{array}{c}\text { Std. } \\
\text { Deviation }\end{array}$ \\
\hline Hasil Evaluasi Ujian ANC (Y) & 34 & 58 & 94 & 77,65 & 8,630 \\
Keaktifan Praktikum (X) & 34 & 3 & 9 & 6,85 & 1,438 \\
\hline
\end{tabular}

Tabel 2 Keaktifan Praktikum

\begin{tabular}{lcc}
\multicolumn{1}{c}{ Kategori } & Frekuensi & $\begin{array}{c}\text { Persentase } \\
(\%)\end{array}$ \\
\hline Tinggi & 32 & 88,2 \\
Rendah & 4 & 11,8 \\
Total & 34 & 100 \\
\hline
\end{tabular}

Tabel 3 Hasil Evaluasi Ujian ANC

\begin{tabular}{lcc}
\hline \multicolumn{1}{c}{ Kategori } & Frekuensi & $\begin{array}{c}\text { Persentase } \\
(\%)\end{array}$ \\
\hline Sangat Baik & 13 & 38,2 \\
Baik & 16 & 47,1 \\
Cukup & 5 & 14,7 \\
Total & 34 & 100 \\
\hline
\end{tabular}

Tabel 4 Tabulasi Silang Hubungan Keaktifan Praktikum dengan Hasil Evaluasi Ujian ANC

\begin{tabular}{cccccc}
\hline Kektifan & \multicolumn{4}{c}{ Hasil Evaluasi Ujian ANC (Y) } & \\
\cline { 2 - 5 }$(\mathrm{X})$ & & Sangat Baik & Baik & Cukup & Total \\
\hline Tinggi & Frekuensi & 13 & 14 & 3 & 30 \\
& \% dengan var.X & $43,3 \%$ & $46,7 \%$ & $10 \%$ & $100 \%$
\end{tabular}




\begin{tabular}{|c|c|c|c|c|c|}
\hline & $\begin{array}{l}\text { \% dengan } \\
\text { Var.Y }\end{array}$ & $100 \%$ & $87,5 \%$ & $60 \%$ & $88,2 \%$ \\
\hline & \% Total & $38,2 \%$ & $41,2 \%$ & $8,8 \%$ & $88,2 \%$ \\
\hline \multirow[t]{4}{*}{ Rendah } & Frekuensi & 0 & 2 & 2 & 4 \\
\hline & $\%$ dengan var.X & $0 \%$ & $50 \%$ & $50 \%$ & $100 \%$ \\
\hline & $\begin{array}{c}\text { \% dengan } \\
\text { Var.Y }\end{array}$ & $0 \%$ & $12,5 \%$ & $40 \%$ & $11,8 \%$ \\
\hline & \% Total & $0 \%$ & $5,9 \%$ & $5,9 \%$ & $11,8 \%$ \\
\hline \multirow[t]{2}{*}{ Total } & Frekuensi & 13 & 16 & 5 & 34 \\
\hline & $\%$ dengan var.X & $38,2 \%$ & $47,1 \%$ & $14,7 \%$ & $100 \%$ \\
\hline \multirow[t]{2}{*}{2} & $\begin{array}{c}\text { \% dengan } \\
\text { Var.Y }\end{array}$ & $100 \%$ & $100 \%$ & $100 \%$ & $100 \%$ \\
\hline & $\%$ Total & $38,2 \%$ & $47,1 \%$ & $14,7 \%$ & $100 \%$ \\
\hline
\end{tabular}

Tabel 5 Analisis Pearson Product Moment Hubungan Keaktifan Praktikum Dengan Hasil Evaluasi Ujian ANC

\begin{tabular}{llrr}
\hline & & $\begin{array}{c}\text { Keaktifan } \\
\text { Praktikum (X) }\end{array}$ & $\begin{array}{r}\text { Hasil Evaluasi } \\
\text { Ujian ANC (Y) }\end{array}$ \\
\hline Keaktifan Praktikum (X) & Pearson Correlation & 1 & .645 \\
& Sig. (2-tailed) & & .000 \\
& $\mathrm{~N}$ & 34 & 34 \\
\hline Hasil Evaluasi Ujian ANC (Y) & Pearson Correlation & .645 & 1 \\
& Sig. (2-tailed) & .000 & 34 \\
& $\mathrm{~N}$ & 34 & \\
\hline
\end{tabular}

Kegiatan belajar-mengajar baik pembelajaran teori maupun praktikum, mahasiswa harus aktif sendiri termasuk strategi yang harus ditempuh untuk mendapatkan sesuatu pengetahuan atau nilai. (Sardiman, 2012) Berdasarkan Tabel 1. dapat dilihat bahwa variabel hasil evaluasi ujian ANC memiliki nilai skor minimum 58 dan nilai maksimum 94 dengan ratarata 77,65. Untuk variabel keaktifan praktikum memiliki nilai skor minimum 3 dan nilai skor maksimum 9 dengan nilai rata-rata 6,85. Belajar perlu ada aktivitas, sebab pada prinsipnya belajar itu adalah berbuat, "learning by doing". (Sardiman, 2012)

Berdasarkan hasil penelitian menunjukkan bahwa keaktifan praktikum mayoritas tinggi sebanyak 32 responden (88,2\%). Aktivitas belajar adalah kegiatan belajar atau aktivitas yang bersifat fisik maupun mental, kaitan keduanya akan membuahkan aktivitas belajar optimal. (Sardiman, 2012). Kegiatan mahasiswa tidak hanya sebatas mendengarkan dan mencatat, banyak aktivitas yang dapat dilakukan seperti yang dikemukanan oleh Paul B. Diedrich dalam Sardiman (2010) antara lain visual activities, oral activities, listening activities, writing activities, drawing activities, motor activities, mental activities, dan emotional activities.

Hasil evaluasi ujian ANC pada mahasiswa mayoritas dalam kategori baik sebanyak 16 responden $(47,1 \%)$. Hasil penelitian ini didukung oleh 
penelitian yang lain bahwa nilai rata-rata mahasiswa dalam ujian praktikum dengan metode OSCE dan non OSCE sudah baik dengan nilai rata-rata $>70,00$ sebagai batas kelulusan. (Latifah, 2013) Ujian praktik Antenatal Care merupakan suatu kegiatan evaluasi untuk menilai hasil belajar mahasiswa melalui teori-teori di kelas maupun Praktik Klinik Kebidanan (PKK) di lahan. Ujian Praktik ANC berupa penilaian praktik yang berfokus pada kemampuan pengetahuan dan keterampilan yang didasarkan pada kemampuan keterampilan secara komprehensif yaitu: pengambilan kasus ibu hamil/ ANC yang meliputi manajemen kebidanan, keterampilan klinik dan pengambilan keputusan serta perencanaan tindakan. (STIKESMUS, 2018) Hasil penelitian ini juga didukung penelitian yang lain bahwa instrumen evaluasi mini-CEX sangat efektif digunakan pada praktek klinik kebidanan terutama dalam pencapaian kompetensi melakukan pemeriksaan kehamilan. (Purba, 2017) Evaluasi ujian ANC dapat digunakan sebagai sarana atau alat untuk mengetahui kemampuan mahasiswa dan untuk bisa meningkatkan kompetensi mahasiswa kebidanan dalam pelayanan antenatal care.

Komponen pertama penilaian ujian ANC adalah pengkajian data subjektif dan data objektif. Pemeriksaan antepartum terdiri dari pengkajian fisik, riwayat lengkap dan pemeriksaan panggul. Bidan perlu mengumpulkan riwayat kehamilan yang terkini, selain mengumpulkan informasi tentang identitas wanita, riwayat keluarga, riwayat menstruasi, riwayat kebidanan, riwayat kandungan, riwayat seksual dan riwayat kontrasepsi. (Varney,2007)

Pemeriksaan penunjang pada komponen penilaian Ujian ANC meliputi pemeriksaan Hemoglobin sahli, urin protein dan urin reduksi. Tes hemoglobin dilakukan untuk mengetahui apakah ibu kekurangan darah (anemia) karena kondisi anemia dapat mempengaruhi proses tumbuh kembang janin dalam kandungan. (Kemenkes RI, 2015) Pemeriksaan kadar hemoglobin darah ibu hamil dilakukan minimal sekali pada trimester pertama dan sekali pada trimeter ketiga. (Kemenkes RI, 2010) Tes laboratorium spesimen urine diambil pada setiap kunjungan ANC guna mengetahui kandungan protein dan glukosa didalamnya. Tes laboratorium dan tes penunjang lain dilakukan jika temuan yang diperoleh pada pengkajian riwayat, pemeriksaan fisik, dan pemeriksaan panggul serta tes laboratorium sebelumnya mengindikasikan pemeriksaan diagnostik lebih lanjut. (Varney, 2007) Pemeriksaan protein dalam urin ditujukan untuk mengetahui adanya proteinuria pada ibu hamil yang merupakan salah satu indikator terjadinya pre-eklamsia pada ibu hamil. Ibu hamil yang dicurigai menderita Diabetes Melitus harus dilakukan pemeriksaan kadar gula darah selama kehamilannya minimal sekali pada trimester pertama, sekali pada trimester kedua dan sekali trimester ketiga (terutama pada akhir trimester ketiga). (Kemenkes RI, 2010)

Komponen penilaian ujian ANC juga termasuk penilaian pendidikan kesehatan. Tenaga kesehatan memberi penjelasan mengenai perawatan kehamilan, pencegahan kelainan bawaan, persalinan dan inisiasi menyusu dini (IMD), nifas, perawatan bayi baru lahir, ASI eksklusif, keluarga 
berencana dan imunisasi pada bayi. Penjelasan ini diberikan secara bertahap pada saat kunjungan ibu hamil. (Kemenkes RI, 2015) Komunikasi yang baik antara tenaga kesehatan profesional dan ibu hamil sangat penting. Komunikasi, informasi dan edukasi yang disampaikan harus didukung oleh informasi berbasis bukti dan tertulis yang disesuaikan dengan kebutuhan wanita. Asuhan dan informasi yang diberikan pada ibu hamil harus sesuai dengan budaya. (NICE,2008)

Bidan sesuai dengan wewenang dan ruang lingkup praktiknya berdasarkan ilmu dan kiat kebidanan sebagai acuan dalam proses pengambilan keputusan dan tindakan asuhan kebidanan. Pelayanan ANC dilaksanakan mulai dari pengkajian, perumusan diagnosa dan atau masalah kebidanan, perencanaan, implementasi, evaluasi dan pencatatan asuhan kebidanan dalam bentuk SOAP (Subjektif, Objektif, Assessment, Penatalaksanaan). (Kemenkes RI, 2007) Penilaian dokumentasi atau pencatatan dalam ujian ANC juga memiliki peran penting, bahwa pencatatan hasil pemeriksaan merupakan bagian dari standar pelayanan antenatal terpadu yang berkualitas. (Kemenkes RI, 2010) Dokumentasi digunakan sebagai suatu keterangan, baik tertulis maupun terekam, mengenai data subyektif yang diambil dengan anamnesa (wawancara), hasil pemeriksaan fisik, hasil pemeriksaan penunjang (laborat, USG dsb), analisa (diagnosa), perencanaan dan pelaksanaan serta evaluasi, tindakan medis,pengobatan yang diberikan kepada klien baik rawat jalan maupun rawat inap, serta pelayanan gawat darurat. (Handayani,2017) Pada saat ini pencatatan hasil pemeriksaan antenatal masih sangat lemah, sehingga data-datanya tidak dapat dianalisa untuk peningkatan kualitas pelayanan antenatal. Dengan menerapkan pencatatan sebagai bagian dari standar pelayanan, maka kualitas pelayanan antenatal dapat ditingkatkan. Oleh karena itu komponen penilaian dokumentasi pada ujian ANC sangat penting dalam rangka meningkatkan kompetensi mahasiswa kebidanan. (Kemenkes RI, 2010)

Tabulasi silang hubungan keaktifan praktikum dengan hasil evaluasi ujian ANC diketahui bahwa mahasiswa yang hasil evaluasi ujian ANC dalam kategori sangat baik, semuanya termasuk dalam kategori keaktifan praktikum tinggi. Melakukan evaluasi taraf keberhasilan rencana dan pelaksana kegiatan belajar mengajar perlu dilaksanakan untuk mengetahui sejauh mana taraf keberhasilan belajar mengajar secara tepat (Valid) dan dapat dipercaya (reliable), sehingga memerlukan informasi yang didukung oleh data objektif dan memadai tentang indikator perubahan perilaku dan pribadi peserta didik. (Makmun, 2012) Hasil belajar atau prestasi belajar seseorang sesuai dengan tingkat keberhasilan sesuatu dalam mempelajari materi pelajaran yang dinyatakan dalam bentuk nilai atao rapor setiap bidang studi setelah mengalami proses belajar mengajar. (Hamdani, 2011) Pada mahasiswa kebidanan memiliki kesempatan belajar teori dan praktik di dalam kelas, laboratorium dan praktik klinik kebidanan dalam melaksanakan asuhan antenatal care pada ibu selama kehamilan. Oleh karena itu, untuk memastikan mahasiswa memiliki kompetensi maka diperlukan suatu 
penilaian untuk mengukur kompetensi tersebut melalui ujian ANC. (Latifah, 2013)

Hasil analisis menunjukkan bahwa nilai p $(0,000)<0,005$ yang menandakan bahwa hubungan antara keaktifan praktikum dengan Hasil evaluasi ujian ANC Pada Mahasiswa Prodi DIII Kebidanan STIKES Mamba'ul 'Ulum Surakarta adalah signifikan. Nilai korelasi adalah positif 0,645 dimana besaran angka korelasi menunjukkan bahwa korelasi antara keaktifan praktikum dengan Hasil evaluasi ujian ANC berada dalam kategori kuat. Hasil penelitian ini didukung oleh penelitian sebelumnya bahwa Keaktifan praktikum memiliki hubungan yang positif dan signifikan dengan keterampilan pemasangan AKDR pada mahasiswa DIII kebidanan dengan nilai $p$ value $=0,020(\mathrm{p}<0,05)$. (Lieskusumastuti, 2014) Hasil penelitian ini juga didukung oleh penelitian sebelumnya tentang hubungan metode pembelajaran simulasi dan belajar mandiri dengan hasil evaluasi belajar ANC menunjukkan bahwa terdapat hubungan yang signifikan metode pembelajaran simulasi dan belajar mandiri dengan hasil evaluasi belajar Asuhan Antenatal Care (ANC) di Akademi Kebidanan Ika Bina Labuhanbatu, melalui uji simultan (ANOVA) yaitu $F=14,750$, dan $p=0,000$. (Tanjung, 2016) Belajar melalui praktik atau mengalami secara langsung seperti melakukan pelayanan Antenatal di laboratorium akan lebih efektif mampu membina sikap, keterampilan, cara berpikir kritis dan lain-lain, bila dibandingkan dengan belajar hafalan saja. (Sardiman, 2012).

\section{SIMPULAN DAN SARAN}

\section{Simpulan}

Keaktifan praktikum Mahasiswa Prodi DIII Kebidanan STIKES Mamba'ul 'Ulum Surakarta mayoritas termasuk kategori tinggi sebanyak 32 responden (88,2\%). Hasil evaluasi ujian ANC Mahasiswa Prodi DIII Kebidanan STIKES Mamba'ul 'Ulum Surakarta mayoritas termasuk kategori baik sebanyak 16 responden (47,1\%). Ada hubungan signifikan antara keaktifan praktikum dengan hasil evaluasi ujian ANC Pada Mahasiswa Prodi DIII Kebidanan STIKES Mamba'ul 'Ulum Surakarta yaitu dengan nilai $p$ $(0,000)<0,005$.

\section{Saran}

Bagi Institusi STIKES Mamba'ul 'Ulum Surakarta, dari hasil penelitian ini diharapkan STIKES Mamba'ul 'Ulum Surakarta khususnya program studi DIII Kebidanan meningkatkan keaktifan praktikum mahasiswa dalam belajar ANC di laboratorium dengan menyusun jadwal praktikum dengan pendampingan dosen dan mandiri. Bagi Mahasiswa DIII Kebidanan agar aktif belajar di kelas maupun laboratorium khususnya untuk persiapan menghadapi ujian antenatal care dan dapat diimplementasikan dalam 
memberikan asuhan pada ibu hamil yang berkualitas sesuai standar praktik bidan. Bagi Peneliti Selanjutnya diharapkan hasil penelitian ini dapat memberikan masukan bagi peneliti selanjutnya untuk meneliti faktor-faktor lain yang berhubungan dengan hasil evaluasi ujian ANC mahasiswa kebidanan.

\section{DAFTAR PUSTAKA}

Dimyati dan Mujdiono. 2009. Belajar dan Pembelajaran. Jakarta: Penerbit Rineka Cipta.

Hamdani, MA. 2011. Strategi Belajar Mengajar. Bandung : Pustaka Setia.

Handayani, ST dan Triwik SM. 2017. Dokumentasi Kebidanan (Bahan Ajar).

Kemenkes RI. http://bppsdmk.kemkes.go.id/pusdiksdmk/wpcontent/uploads/2017/11/DAFIS-DAN-DOKUMENTASI-

KEBIDANAN.pdf

Irianti, Bayu, dkk. 2013. Asuhan Kehamilan Berdasarkan Bukti. Jakarta: Sagung Seto.

Kemenkes RI. 2007. Standar Asuhan Kebidanan. Jakarta. http://www.google.co.id/search?hl=id\&q=standar+asuhan+kebidanan +kepmenkes +2007

Kemenkes RI. 2010. Pedoman Pelayanan Antenatal Terpadu. Jakarta: Kementerian Kesehatan RI dan Direktur Jenderal Bina Kesehatan Masyarakat.

Kemenkes RI. 2015. Buku Kesehatan Ibu dan Anak. Jakarta : Kemenkes dan JICA (Japan International Cooperation Agency) 1997.

Latifah, Ulfatul. 2013. Perbedaan Hasil Belajar Praktikum Asuhan Kehamilan Dengan Metode OSCE (Objective Structured Clinical Examination) Dan

Non OSCE Untuk Mahasiswa Kebidanan. http://ojs.stikesbhamada.ac.id/ojs/index.php/jitk/article/viewFile/11 $\underline{4 / 174}$

Lieskusumastuti, AD. 2014. Hubungan Keaktifan Praktikum, Pengetahuan dan Motivasi Dengan Keterampilan Pemasangan AKDR pada mahasiswa DIII Kebidanan. Tesis Diterbitkan. Surakarta: Universitas Sebelas Maret Surakarta

Makmun, Abin Syamsudin. 2012. Psikologi Kependidikan - Perangkat Sistem Pengajaran Modul. Bandung: Remaja Rosdakarya.

Marniyati, L, Irsan S, Bambang BS. 2016. Pelayanan Antenatal Berkualias dalam Meningkatkan Deteksi Resiko Tinggi Pada Ibu Hamil Oleh Tenaga Kesehatan di Puskesmas Sako, Sosial, Sei Baung dan Sei Selincah di Kota Palembang. Jurnal Kedokteran dan Kesehatan Volume 3 No 1 Januari 2016 Program Pascasarjana Ilmu Kesehatan Masyarakat Universitas Sriwijaya Palembang. https://media.neliti.com/media/publications/181709-ID-pelayananantenatal-berkualitas-dalam-me.pdf 
NICE (National Institute for Health and Clinical Excellence: Guidance). 2008. Antenatal Care: Routinee Care For The Healthy Pregnant Woman. National Collaborating Centre for Women's and Children's Health (UK). London: RCOG Press. https://www.ncbi.nlm.nih.gov/pubmed/21370514

Purba, A dan Elsarika D. 2017. Efektifitas Mini-Cex Terhadap Hasil Evaluasi Praktik Pemeriksaan Kehamilan Di Klinik Bersalin Kabupaten Deli Serdang. Idea Nursing Journal Volume III Nomer 22017 (Online). http://jurnal.unsyiah.ac.id/INJ/article/download/8822/7421

Sardiman, A.M. 2012. Interaksi Dan Motivasi Belajar Mengajar. Jakarta : Rajawali Pers.

STIKES Mamba'ul 'Ulum Surakarta. 2017. Panduan Ujian Phantom dan Antnatal Care (ANC) Prodi DIII Kebidanan Tahun Akademik 2017/2018. Surakarta : STIKES Mamba'ul 'Ulum

Tanjung, RDS. 2016. Faktor-Faktor Yang Mempengaruhi Hasil Belajar Asuhan Antenatal Care Di Akademi Kebidanan Ika Bina Labuhantu. Jurnal Manajemen Pendidikan Indonesia Volume 8 No 1 (Online). http://jurnal.unimed.ac.id/2012/index.php/jmpi/article/view/7859

Varney, Helen. 2007. Buku Ajar Asuhan Kebidanan Edisi 4 Volume 1. Alih Bahasa: Ana Lusiyana. Jakarta : EGC

Yanuaria, MR dan Ratna DW. 2013. Penyusunan Upaya Peningkatan Pelayanan Antenatal Care Berdasarkan Voic of The Customer. Jurnal Administrasi Kesehatan Indonesia Volume 1 Nomor 1 Januari - Maret 2013 (online). http://journal.unair.ac.id/filerPDF/6.\%20Myrra\%20Rizky JAKIv1n1.p $\underline{\mathrm{df}}$ 
